\title{
PRESENT SITUATION OF ICT ENABLED MODERNIZED SERVICES IN THE COLLEGE LIBRARIES UNDER WEST BENGAL STATE UNIVERSITY
}

\author{
Paramita Sen \\ Librarian, Chandraketugarh Sahidullah Smriti Mahavidyalaya, \\ Debalaya, Berachampa, India

\section{Dr. Subarna Kumar Das} \\ Professor, Dept. of Library \& Information Science, \\ Jadavpur University, Kolkata, India
}

\begin{abstract}
In general, a college library is regarded as an institution of higher learning, which usually offers a three years or a four years course after school leading to a bachelor's degree. Beside the traditional services library renders new services like automated circulation, web-OPAC and use of e-resources 24 hours from home, e-CAS facility etc to make library services updated with the new era and to satisfy the ever growing need of the users today. In general staff of any library is divided into four types: Professional, Semi - professional, non - professional and Technical staff. Among the 42 govt. and govt. aided general degree colleges 16 colleges are surveyed from which 15 colleges responded to the survey. Among the colleges responded to our survey there are 3 Govt. Degree colleges and 12 govt. aided general degree colleges. This study is done through the survey method and a questionnaire was given to each college. The data collected from the survey are analyzed and concluded through the results and recommendations for future scope of research in this area.
\end{abstract}

Key words: Library services, Staff formula, College libraries, West Bengal State University

Cite this Article: Paramita Sen, Dr. Subarna Kumar Das, Present Situation of ICT Enabled Modernized Services in the College Libraries under West Bengal State University, International Journal of Library \& Information Science, 8(3), 2019, pp. 39-49.

http://www.iaeme.com/IJLIS/issues.asp?JType=IJLIS \&VType=8\&IType=3 


\section{INTRODUCTION}

As ICT is emerging every sphere of our life and activities to make the work easier and quicker, library is not also lagging behind. To render effective services we should have well equipped library with good number of resources as well as efficient staff. Beside the traditional services library renders new services like automated circulation, web-OPAC and use of e-resources 24 hours from home, e-CAS facility etc to make library services updated with the new era and to satisfy the ever growing need of the users today. The users of academic libraries like general degree college library are mainly the students and teachers of the institute. So the staff strength depends upon the number of collections, number of users, need of the users etc. Socio-economic condition of the students and locality also affects the information need of them. This study attempts to give an overall picture of the undergraduate colleges of West Bengal State University through the survey in the college libraries.

\section{DEFINITION OF THE TERMS}

\subsection{College Library}

In general, a college library is regarded as an institution of higher learning, which usually offers a three years or a four years course after school leading to a bachelor's degree. A college library must fulfill the basic needs to support the teaching, research and study requirements of the academic community, if it is to be a place of intellectual workshop: a clear statement, which governs the relationship of the librarian and the other components of the college, like the faculty community and provides appropriately shared responsibility and activity among them; recognition of library as an academic development of the collegeimparting library centered education to students as well as an academic information center with academic activities including library-based teaching.

\subsection{Staff Pattern}

In general staff of any library is divided into four types:

Professional: Professional staff is well qualified and trained in LIS and can manage the library independently with responsibility. Under this category the different positions like librarian, deputy librarian and assistant librarian are included.

They are well qualified and having different skills.

Semi - Professional: In this category the library assistants, cataloguers, classifiers, indexers, library clerks are covered having less qualification or graduate in LIS. The task carried out by this group is managing acquisition, organization and processing of the documents providing information services etc. under the supervision of professional staff.

Non - Professional: This category of staff is supporting staffs and helps in who under take administrative jobs like stenography, clerical work, finance and managing correspondence.

Technical Staff: this category of staff manages Xeroxing operation of different machines in libraries maintaining equipment's etc.

\subsection{Staff Formula}

The first staffing formulae is based on the recommendations made by library committee under the chairmanship of Dr. S R Ranganathan in 1958. This formula was modified later in 1965 and 1979 by UGC. The efforts made by Dr S R Ranganathan while developing staff formulae is based on different sections of library to identify different sections of library its workflow and requirement of staff to manage the activity. 
The different formulae was criticized by D.B Madiwale (1985 pp 265-275) in his communication presented at ILA conference in 1985. He suggested a formula for college libraries in India in 1979 at the UGC conference. Further he has suggested the staff as under:

Librarian: From beginning of the college. The librarian is responsible for planning and developing the library of the college and provides the necessary library service to the students and staff of the college. He is responsible and report to the principal in all matters connected with the library activities. The job of responsibility is :

- To manage the library efficiently by looking after general administration of the library .

- Preparing annual budget.

- Looking after acquisition of book / periodicals / video tapes/e-resources including its selection.

- Planning and developing the library for modernizing and overall supervision.

Assistant librarian: After enrolment of 1000 students. Now the post of Assistant librarian is discontinued and post of $2^{\text {nd }}$ librarian created when the collection of book exit 20000 in a college library.

Library Assistant: (a) From the beginning of the college - one. (b) In addition to the above for every 750 students one library assistant to be added. The library assistants are responsible to support the activities carried out by assistant librarian and the librarian. The Job Description covers Issuing and receiving of books, replacing the books and periodicals etc.

Clerk - cum Typist: From beginning of the college library - one staff will be recruited with minimum H.S. qualification and Certificate course of Library and Information Science

Library Attendant: (a) From beginning of the college library - two. In addition to the above, for every addition of 1000 students - one. The library attendants are helpers to librarian and assistant librarians. The Job Description covers checking at entrance, control over property counter, maintenance and upkeep of library, labeling and pasting, repair of books etc.

Technical Assistants: After the enrolment of 2000 students.

\subsection{Historical Background of West Bengal State University}

West Bengal State University, commonly known as WBSU and Barasat University is a public university situated in Barasat, North 24 Paraganas, near the city of Kolkata, West Bengal,India. All the 59 colleges (including Undergraduate, Postgraduate and B.Ed) in the district of North 24 Parganas, which were formerly affiliated with the University of Calcutta, are affiliated to this university. The Government of West Bengal through an Act of the Legislative Assembly has passed West Bengal Act XXVIII, 2007 implementing a longstanding public demand in creating the university named West Bengal State University at Barasat, North 24 Paraganas. This became functional from the academic session 2008-09. They were, through a government notification transferred to this new university. The University began functioning under its first Vice-Chancellor Professor Ashoke Ranjan Thakur, the erstwhile Pro-Vice-Chancellor of Jadavpur University. Now there are 42 Govt. and Govt. aided colleges under this university.

\section{LITERATURE REVIEW}

The need for the library to intensify its efforts in educating the library users through setting up of additional methods of user education in order to achieve excellence in educational pursuit was advocated by Esse in his article (Esse, 2014). Some researchers have promoted the use of ICT in the delivery of library services to the library patrons. Studies have shown that 
integration of ICT in learning increase the skill, learning and academic performance of students and staff.

According to Omeluzor, integration of ICT helps students' intellectual ability and skill for accessing and retrieving information as well as constructing a framework for learning. He suggested in the study that faculty and library staff should work closely in achieving information literacy and ICT literacy training for their students and staff.(Omeluzor,2017) Integration of ICT with LI increases awareness, skill and knowledge of the library users in using electronic information resources effectively, thereby boosting students' academic performance (Mbugua,2015).

There are so many different types of electronic information resources available in the world such as E-books, E-journals, Databases, Internet gateways and search engines, etc. Many library users have preferred e-resources rather than printed resources due to the various reasons, such as it's easier to access, search, store, retrieve, share and use. Therefore, library should encourage the users to refer the e-resources more and more to get the benefits out of it. But, Majority of the library users does not have sufficient knowledge and skills to use the electronic resources and services effectively.

There are few research studies conducted to examine e-resources usage and issues related to the e-resources and services among various user categories. Lavanya and Santharooban (2018) carried out a study for examine the usage of online resources by the under graduates attached to the Faculty of Agriculture, Eastern University of Sri Lanka. The study revealed that most of the students access e-resources though smart phones for different educational purposes and student mostly unaware of both open access and University Subscribed online resources. The study also revealed the barriers to access online resources namely, slow internet connectivity, lack of awareness and various virus attack. It is recommended that wellplanned information literacy programs should be introduced for students.

Kumbar, Chikkamanju \& Kumar(2013) was carried out a study at University of Mysore Constituent Colleges such as Maharaja's Arts College and Yuvraja's Science College, Mysore. The studies aim to examine the factors affecting the optimum utilization of N-List Services, place of access, purpose of use, types of services, level of satisfaction, problem faced while accessing, training/ orientation program and preferred external storage medium for storing information resources downloaded via N-List Services. For this purpose the researchers prepared a well structured questionnaire and interview schedule as a tool for data collection and same was analyzed and presented with useful percentage analysis and suitable table for presentation of data. The article summarizes the results highlighting the major findings, suggestions and conclusion.

Khandare \& Sonwane(2015) in their paper "Access to E-resources under N-List Consortium: A survey of Libraries in Maharashtra" said that UGC-INFONET digital library consortium was not considered feasible for the colleges and practicall are not required at college level students, so a smaller bouquet with selected titles has been prepared under a new programme $\mathrm{N}$-List and it is being offered to colleges only. It facilitates access to e-resources to students, researchers and faculty from colleges through proxy servers. N-List provides scholarly information in the e-format at discounted rates.

Another study deals with the utilization of N-LIST digital library programme by the faculty members and students of Gokhale Centenary College, Ankola. The result show large percent of users preferred electronic journals when compared to print version of primary journals at Gokhale Centenary College, Ankola. E-Resources were mostly used for upgrade their knowledge and announce their career development, assignments, conference and seminars (Verma,2009). 
A study by Waghmare \& Ramanna aims at ascertaining the awareness of N-LIST programme among science and social science teachers of selected colleges, understand the usage pattern and preferences, level of satisfaction, the need for orientation programmes and the various suggestions put forward by the users. The questionnaire method was used for the study. Questionnaires were distributed to science and social science faculty members of five colleges. Most of the respondents were aware of N-LIST and majority of them came to know about N-LIST from their college librarian. It is found that teachers above the age of 45 years access N-LIST more than teachers of other age groups. Those in science subjects access NLIST more. The teachers access N-LIST for preparing articles, teaching, preparing presentations for projects etc. Though they find N-LIST very useful, they face certain problems such as slow Internet connectivity and lack of infrastructure in colleges and limited resources available in NLIST.A few of the respondents have suggested that more resources such as Science Direct may be included in N-LIST. It is hoped that programme will be accessible to more colleges with a wider coverage in future. (Waghmare \& Ramanna,2014)

\section{OBJECTIVE OF THE STUDY}

The study is conducted to establish a survey on the present situation and condition of the staff strength, services rendered both traditional and modernized to the users of the college libraries under West Bengal State University. The study attempt to make a state-of-the art report on the analysis of the data collected from the survey to establish the present scenario of the staff structure, collections of resources and services of the libraries.

\section{SCOPE OF THE STUDY}

Among the 42 govt. and govt. aided general degree colleges 16 colleges are surveyed from which 15 colleges responded to the survey. Among the colleges responded to our survey there are 3 Govt. Degree colleges and 12 govt. aided general degree colleges.

\begin{tabular}{|c|c|c|c|c|}
\hline Sl. no. & Name of the Colleges & Address & Status & $\begin{array}{l}\text { Survey } \\
\text { status }\end{array}$ \\
\hline 1. & Barasat Govt college & $\begin{array}{l}10 \text { KNC Road, Barasat. Kol - } \\
700124\end{array}$ & Govt. & Responded \\
\hline 2. & P. R Thakur Govt. College & $\begin{array}{l}\text { Thakurnagar, P.S.- Gaighata, } \\
\text { North } 24 \text { Pgs, Pin-743287. }\end{array}$ & Govt. & Responded \\
\hline 3 & Taki Govt. College & Taki, North 24 Pgs,Pin-743429 & Govt. & Responded \\
\hline 4 & Banipur Mahila Mahavidyalaya & $\begin{array}{l}\text { P.O.- Banipur, North } 24 \\
\text { Pgs,Pin-743233 }\end{array}$ & $\begin{array}{l}\text { Govt. } \\
\text { Aided }\end{array}$ & Responded \\
\hline 5 & Barasat College & $\begin{array}{l}\text { 1 Kalyani Road Nabapally, } \\
\text { Kol- } 700126\end{array}$ & $\begin{array}{l}\text { Govt. } \\
\text { Aided }\end{array}$ & Responded \\
\hline 6 & Basirhat College & $\begin{array}{l}\text { Basirhat, North } 24 \text { Pgs, Pin- } \\
743412 \text {. }\end{array}$ & $\begin{array}{l}\text { Govt. } \\
\text { Aided }\end{array}$ & Responded \\
\hline 7 & $\begin{array}{l}\text { Chandraketugarh Sahidullah Smriti } \\
\text { Mahavidlaya }\end{array}$ & $\begin{array}{l}\text { Debalaya(Berachampa), North } \\
24 \text { Pgs, Pin -743424 }\end{array}$ & $\begin{array}{l}\text { Govt. } \\
\text { Aided }\end{array}$ & Responded \\
\hline 8 & DumDum Motijheel College & $\begin{array}{l}\text { 1, Motijheel Avenue, Kol- } \\
700074\end{array}$ & $\begin{array}{l}\text { Govt. } \\
\text { Aided }\end{array}$ & Responded \\
\hline 9 & $\begin{array}{l}\text { Hiralal Mazumdar Memorial College For } \\
\text { Women }\end{array}$ & Dakshineswar, Kolkata-700035 & $\begin{array}{l}\text { Govt. } \\
\text { Aided }\end{array}$ & Responded \\
\hline 10 & Mrinalini Datta Mahavidyapith & $\begin{array}{l}\text { Vidyapith Road, Birati, Kol- } \\
700051\end{array}$ & $\begin{array}{l}\text { Govt. } \\
\text { Aided }\end{array}$ & Responded \\
\hline 11 & $\begin{array}{l}\text { Naba Barrackpore Prafulla Chandra } \\
\text { Mahavidyalaya }\end{array}$ & New Barrackpore, Kol- 700131 & $\begin{array}{l}\text { Govt. } \\
\text { Aided }\end{array}$ & Responded \\
\hline 12 & $\begin{array}{l}\text { Prasanta Chandra Mahalanobish } \\
\text { Mahavidyalaya }\end{array}$ & 111/3,B.T. Road, Kol-700108 & $\begin{array}{l}\text { Govt. } \\
\text { Aided }\end{array}$ & Responded \\
\hline 13 & Panihati Mahavidyalaya & $\begin{array}{l}\text { Barasat Road, Sodepur, Kol- } \\
700110\end{array}$ & $\begin{array}{l}\text { Govt. } \\
\text { Aided }\end{array}$ & Responded \\
\hline
\end{tabular}




\begin{tabular}{|c|l|l|l|l|}
\hline 14 & $\begin{array}{l}\text { R. K. Sarada Mission Vivekananda } \\
\text { Vidyabhavan }\end{array}$ & $\begin{array}{l}33 \text { Nayapatti Road, Dum Dum, } \\
\text { Kol-700055 }\end{array}$ & $\begin{array}{l}\text { Govt. } \\
\text { Aided }\end{array}$ & Responded \\
\hline 15 & Sahid Nurul Islam Mahavidyalaya & $\begin{array}{l}\text { Tentulia, North 24 Parganas, } \\
\text { Pin-743703 }\end{array}$ & $\begin{array}{l}\text { Govt. } \\
\text { Aided }\end{array}$ & Responded \\
\hline 16 & Vivekananda College & $\begin{array}{l}\text { East Udayrajpur, } \\
\text { Madhyamgram,Kol-700129 }\end{array}$ & $\begin{array}{l}\text { Govt. } \\
\text { Aided }\end{array}$ & $\begin{array}{l}\text { Not } \\
\text { responded }\end{array}$ \\
\hline
\end{tabular}

\section{METHODOLOGY}

This study is done through the survey method and a questionnaire has been given to each college and the librarian of the colleges gave the information. On the basis of the collected information the analysis is done and presented in this study through tables and charts.

\section{DATA ANALYSIS}

\subsection{Number of Staff}

\begin{tabular}{|l|c|c|c|c|c|c|}
\hline \multicolumn{1}{|c|}{ Name of the college } & Librarian & $\begin{array}{c}\text { Library } \\
\text { Assistant }\end{array}$ & $\begin{array}{c}\text { Library } \\
\text { Clerk }\end{array}$ & $\begin{array}{c}\text { Library } \\
\text { Attendent } \\
\text { / Peon }\end{array}$ & $\begin{array}{c}\text { Library } \\
\text { Trainee }\end{array}$ & $\begin{array}{c}\text { Casual } \\
\text { Staff }\end{array}$ \\
\hline Barasat Govt college & $\mathbf{1}$ & $\mathbf{2}$ & - & $\mathbf{2}$ & - & - \\
\hline P. R Thakur Govt. College & $\mathbf{1}$ & - & $\mathbf{2}$ & - & - & - \\
\hline Taki Govt. College & $\mathbf{1}$ & $\mathbf{1}$ & - & $\mathbf{1}$ & - & $\mathbf{1}$ \\
\hline $\begin{array}{l}\text { Banipur Mahila } \\
\text { Mahavidyalaya }\end{array}$ & $\mathbf{1}$ & - & - & - & - & $\mathbf{1}$ \\
\hline Barasat College & $\mathbf{1}$ & - & $\mathbf{2}$ & $\mathbf{1}$ & - & - \\
\hline Basirhat College & $\mathbf{1}$ & - & $\mathbf{2}$ & - & $\mathbf{1}$ & - \\
\hline $\begin{array}{l}\text { Chandraketugarh Sahidullah } \\
\text { Smriti Mahavidlaya }\end{array}$ & $\mathbf{1}$ & $\mathbf{1}$ & $\mathbf{1}$ & $\mathbf{1}$ & - & $\mathbf{1}$ \\
\hline $\begin{array}{l}\text { DumDum Motijheel } \\
\text { College }\end{array}$ & $\mathbf{2}$ & - & - & $\mathbf{2}$ & - & - \\
\hline $\begin{array}{l}\text { Hiralal Mazumdar Memorial } \\
\text { College For Women }\end{array}$ & $\mathbf{1}$ & - & - & - & - & $\mathbf{2}$ \\
\hline $\begin{array}{l}\text { Mrinalini Datta } \\
\text { Mahavidyapith }\end{array}$ & $\mathbf{2}$ & - & $\mathbf{1}$ & $\mathbf{2}$ & - & - \\
\hline $\begin{array}{l}\text { Naba Barrackpore Prafulla } \\
\text { Chandra Mahavidyalaya }\end{array}$ & $\mathbf{1}$ & - & $\mathbf{1}$ & $\mathbf{1}$ & - & - \\
\hline $\begin{array}{l}\text { Prasanta Chandra } \\
\text { Mahalanobish } \\
\text { Mahavidyalaya }\end{array}$ & $\mathbf{1}$ & - & - & - & $\mathbf{1}$ & $\mathbf{1}$ \\
\hline Panihati Mahavidyalaya & $\mathbf{1}$ & - & - & $\mathbf{1}$ & - & $\mathbf{2}$ \\
\hline $\begin{array}{l}\text { R. K. Sarada Mission } \\
\text { Vivekananda Vidyabhavan }\end{array}$ & $\mathbf{1}$ & $\mathbf{1}$ & $\mathbf{1}$ & - & - & $\mathbf{2}$ \\
\hline $\begin{array}{l}\text { Sahid Nurul Islam } \\
\text { Mahavidyalaya }\end{array}$ & $\mathbf{1}$ & $\mathbf{1}$ & $\mathbf{2}$ & $\mathbf{2}$ & - & - \\
\hline
\end{tabular}

The above table shows the chart of staff strength of the 15 colleges surveyed for the study. From the chart we clearly that among the 15 colleges 2 colleges have more than 1 librarian, maximum college have vacancy of clerk cum typist post, maximum college have casual and non-professional library staff to assist the librarian to render new services. 


\subsection{Number of Books}

The table shows the collection of books in the college library surveyed for this study. Among the 15 colleges 2 college have books below 10000, maximum colleges have books in the range of 10000-20000, 2 colleges have collection of books more than 50000. They are much enriched and old libraries among the colleges surveyed. Both are Govt. Colleges.

\begin{tabular}{|l|c|}
\hline \multicolumn{1}{|c|}{ Total no. of books } & No. of Colleges \\
\hline $0-10000$ & 2 \\
\hline $10000-20000$ & 7 \\
\hline $20000-30000$ & 3 \\
\hline $30000-40000$ & 1 \\
\hline $40000-50000$ & - \\
\hline 50000 and above & 2 \\
\hline Total & 15 \\
\hline
\end{tabular}

\subsection{Total no. of Students}

The student strength of the colleges are shown through the following table

Among the colleges surveyed 3 colleges have students within the range of 500, 3 colleges have student strength of 1000, 1 college have more than 1000 student strength, 1 college falls in the range of 1500-2000 and 6 colleges have more than 2000 students in total.

\begin{tabular}{|l|c|}
\hline \multicolumn{1}{|c|}{ Total no. of students } & No. of Colleges \\
\hline $0-500$ & 3 \\
\hline $500-1000$ & 3 \\
\hline $1000-1500$ & 1 \\
\hline $1500-2000$ & 2 \\
\hline 2000 and above & 6 \\
\hline Total & 15 \\
\hline
\end{tabular}

\subsection{Traditional Services Rendered by the Library}

The table shows that all the college libraries render traditional services like Circulation, reading facility of books, newspaper, magazines, reference service etc. Some colleges subscribes printed journals for users. Among the 15 colleges 3 college library give reprographic services to the students, 4 colleges render CAS services, 1 college has newspaper clippings services and 1 college gives book bank facility to the students.

\begin{tabular}{|l|c|}
\hline \multicolumn{1}{|c|}{ Services rendered } & No. of colleges \\
\hline Circulation & 15 \\
\hline Reading Room & 15 \\
\hline Printed Journals & 7 \\
\hline Magazine, Newspaper & 15 \\
\hline Reference service & 15 \\
\hline Reprographic Service & 3 \\
\hline Current Awareness Service & 4 \\
\hline Newspaper clippings service & 1 \\
\hline Book bank facility & 1 \\
\hline
\end{tabular}




\subsection{Programmes by the Libraries to Promote Library use}

In this table number of colleges who organize programs for the staff and the students to promote library use among all.

From the above table we come to know that among the 15 colleges surveyed, only 6 college libraries organized orientation programme, 3 organized seminar and workshop and 6 have organized book fair or exhibition to promote use of the library.

\begin{tabular}{|l|c|}
\hline \multicolumn{1}{|c|}{ Programmes } & $\begin{array}{c}\text { No. of } \\
\text { Libraries }\end{array}$ \\
\hline Orientation & 6 \\
\hline Workshop & 3 \\
\hline Seminar & 3 \\
\hline Book fair/Book Exhibition & 6 \\
\hline Others & 0 \\
\hline
\end{tabular}

\subsection{Use of e-Resources}

From this table we can see it clearly that 2 college libraries have no e-resouces, whereas maximum college libraries have $\mathrm{N}$-List programme as e-resource for their users and two colleges among them has more than one source or database of e-journals and e-books for serving their users.

\begin{tabular}{|l|c|}
\hline Nlist & 13 \\
\hline Other e-resources & 2 \\
\hline No e-resources & 2 \\
\hline
\end{tabular}

\subsection{Software use}

The table shows that 14 college library use Koha out of 15 colleges and one college library use SOUL as automation software.

Digital library software Dspace is used for Institutional Repository in one of the 15 colleges surveyed.

\begin{tabular}{|c|c|}
\hline Software & No. of Libraries \\
\hline Automation Software: & \\
\hline Koha & 14 \\
\hline Soul & 1 \\
\hline Libsys & - \\
\hline Others & - \\
\hline Digital library software & 1 \\
\hline
\end{tabular}

\subsection{ICT Infrastructure}

All the colleges have library automation software in use and all the libraries have computers for its staff, only 7 colleges have computer for teachers and 11 colleges have computer terminals for net surfing, OPAC or WEBOPAC searching, e-resource use etc. All the college libraries have internet connectivity and among the 15 colleges 6 have Wi-Fi facilities for library users.

\begin{tabular}{|l|c|}
\hline Computer terminals & No. of colleges \\
\hline For Library Staff & 15 \\
\hline For Teachers & 7 \\
\hline For students & 11 \\
\hline Internet connectivity & 15 \\
\hline Wi-fi facilities & 6 \\
\hline
\end{tabular}


Present Situation of ICT Enabled Modernized Services in the College Libraries under West Bengal State University

\subsection{Security of Library Resources}

About the question of security of library material we see that maximum college libraries are under CCTV surveillance.

\begin{tabular}{|l|c|}
\hline \multicolumn{1}{|c|}{ Security system } & No. of Libraries \\
\hline CCTV & 12 \\
\hline RFID & - \\
\hline Others & - \\
\hline
\end{tabular}

\subsection{Online Catalogue Service Facility}

From the above table we see that all the college libraries have OPAC facilities for the users and among the 15 colleges 4 colleges has Web OPAC facility by which the user can search the catalogue online from home or anywhere outside the library.

\begin{tabular}{|l|c|}
\hline Online Catalogue service & No. of Libraries \\
\hline OPAC & 15 \\
\hline Web OPAC & 4 \\
\hline Total & 15 \\
\hline
\end{tabular}

\section{FINDINGS OF THE STUDY}

From the analysis of the collected data the findings are-

- Among the 15 colleges 2 college have books below 10000, maximum colleges have books in the range of 10000-20000, 2 colleges have collection of books more than 50000,Among the colleges surveyed 6 colleges have more than 2000 students in total.

- Among the 15 colleges, 3 colleges give reprographic services to the students, 4 colleges render CAS services, 1 college has newspaper clippings services and 1 college gives book bank facility to the students.

- Among the surveyed colleges, only 6 college libraries organized orientation programme, 3 colleges organized seminar and workshop and 6 colleges have organized book fair or exhibition to promote use of the library.

- Maximum college libraries have N-List programme as e-resources for their users. 14 college library use Koha out of 15 colleges and one college library use SOUL as automation software. Digital library software Dspace is used for Institutional Repository in one of the 15 colleges surveyed.

- All the college libraries have internet connectivity and among the 15 colleges 6 have Wi-Fi facilities for library users and maximum college libraries are under CCTV surveillance.

- All the college libraries have OPAC facilities for the users and among the 15 colleges 4 colleges has Web OPAC facility by which the user can search the catalogue online from home or anywhere outside the library.

- Here is scarcity of professional staff to render services in an efficient and satisfactory way.

- Lack of compatibility of ICT among the library staff is prominent problem to start new services.

- Lack of fund for library resources, equipment are also a problem for development.

\section{SUGGESTIONS}

From this analysis we can conclude by the Future recommendation for the growth and development of library resources including human resources and services through the following suggestions: 
- More staff has to be recruited for smooth running of the library activities and introduce new services.

- The library staff other than the librarian should be minimum certificate course holder of Library and Information Science so that they can assist the librarian.

- The library staff should be oriented properly to avoid professional hazards and smooth running of the library.

- Short term courses, Work shop should be organized for library staff at regular basis so that they can able to be acquainted with modernized services and render effective services to satisfy the users.

- College authority should raise more funds for library so that the collections and services can be upgraded for the users.

- More orientation programmes, user education programmes should be done so that the users can also be able to use the modernized services implemented in the library.

\section{CONCLUSION}

Through this study one can get a fair idea of the situations and conditions of the college libraries under West Bengal State University with a SWOC analysis of the staff structure, collections, user strength, traditional as well as modernized services rendered by the libraries. The survey is done for hands on experience about the activities of college libraries and suggestions for further development so that many new services emerging in this ICT era can be rendered through these libraries and the libraries can play a major role at present and in future also.

\section{REFERENCES}

[1] Esse, U.C. Effects of library instruction on satisfaction with the use of library and its services: A study of undergraduate students in five universities in the Southern part of Nigeria. Eur. Sci. J., 2014, 10(13), 441-450.

[2] Khandare, Rahul B. \& Sonwane, Shashank S. (2015, Nov.). Access to E-resources under N-List Consortium: A survey of Libraries in Maharashtra. Journal of Library, Information and Communication Technology Vol.7 (3-4), pp.11-26.

[3] Kumbar, Mallinath, Chikkamanju \& Kiran Kumar, G. (2013). Use of N-LIST services by faculty and students of University of Mysore. In National Seminar on Emerging Trends in ERMS in College Libraries, September 27 \& 28, 2013.

[4] Lavanya, J. \& Santharooban, S. (2018). Usage of online resources by the under graduates attached to the Faculty of Agriculture, Eastern University, Sri Lanka. Journal of the University Librarian Association of Sri Lanka, 21(2), 89-105. https://doi.org/10.4038/jula.v21i2.7919

[5] Madukoma, E.; Onuoha, U.D.; Omeluzor, S.U. \& Ogbuiyi, S. Library instruction and academic performance of undergraduates at Babcock University, Nigeria. Contem. Humanit., 2013, 6, 39-58.

[6] Mbugua, S.N.; Kiboss, J. \& Tanui, E. Influence of integration of information communication technology in teaching on students' academic performance. J. Educ, Pract., 2015, 6(24), 7-13.

[7] Miima, F.A. Integration of information communication technologies in teaching and learning of Kiswahili language in public secondary schools in Kakamega County, Kenya. A research thesis submitted to the department of educational communication and technology, School of Kenyatta University, 2014. 
Present Situation of ICT Enabled Modernized Services in the College Libraries under West Bengal State University

[8] Natarajan, K. et. al.(2010). Use and user perception of electronic resources in Annamalai University: A case study. Annals of Library and Information studies, Vol 57; pp.59-64.

[9] N-LIST: National Library and Information Services Infrastructure for Scholarly Content. Retrieved from http://nlist.inflibnet.ac.in on 25.06.2019.

[10] Ololube, N.P.; Eke, P.; Uzorka, M.C. \& Ekpenyong, N.S. Instructional technology in higher education: A case of selected universities in the Nigeria Delta. Asian-Pacific Forum on science learning and teaching, 2009, 10(2), 1.

[11] Omeluzor, S.U.; Akibu, A.A. \& Akinwoye, O. Students' perception, use and challenges of electronic information resources in Federal University of Petroleum Resources Effurun Library in Nigeria. Libr. Philos. Pract. (e-journal). Paper 1428. http://digitalcommons.unl.edu/ libphilprac/1428(accessed 22 April 2017).

[12] Santhi, L. \& Radhakrishnan, N. (2014). Usage Pattern of Electronic Resources among the Research Scholars in Anna University of Technology, Coimbatore and Its Affiliated Colleges. IOSR Journal of Humanities and Social Science (IOSR-JHSS).Vol. 19(7),pp.2326.

[13] Verma, Shilpi...et al.(2009).Use of Electronic Resources in the Library of Sikkim Manipal Institute of Technology (SMIT), Sikkim : A Study. In International Conference on Academic Libraries, Delhi, Indian, October 5-8 2009, Delhi University Library System, University of Delhi (North Campus) Delhi, pp. 660-663. Retrieved from http://crl.du.ac.in/ical09/papers/index_files/ical-114_102_231_2_RV.pdf.

[14] Waghmare, Prakash B and Ramanna, Shamrao(2014, Jan-Mar). Library Use and Promotion of Library Use by Faculty Members in Affiliated Colleges of Gulbarga University Gulbarga, Karnataka (India). International Journal of Library and Information Studies: An online Journal, Vol 4(1), pp.32-37.

[15] West Bengal State University. Retrieved from https://en.wikipedia.org/wiki/West_Bengal_State_University on 26.06.2016. 